\title{
Ontario's University Tuition Framework: A History and Current Policy Issues
}

\author{
Andrew Michael Boggs \\ University of Oxford
}

\begin{abstract}
Policy-makers and institutional administrators have long struggled with the question of college and university student tuition fees. In many ways this struggle may be characterized as a negotiation between two distinct policy goals: providing revenue to adequately finance higher education and ensuring student accessibility to higher education. The Government of Ontario has wrestled with these competing questions, resulting in major changes to tuition policy over the last 10 years. This article discusses the history of tuition policy in Ontario, recent developments, and outstanding policy challenges relating to institutional behaviour toward the current policy, set to expire in 2009-10.
\end{abstract}

\section{RÉSUMÉ}

Les responsables politiques et les administrateurs institutionnels ont eu longtemps fort à faire avec la question des droits d'inscription dans les collèges et les universités. De divers points de vue, cette problématique peut être caractérisée par la nécessité de concilier deux objectifs politiques distincts : d'une part, fournir des revenus suffisants pour financer l'éducation supérieure et, d'autre part, assurer aux étudiants l'accessibilité à cette même éducation supérieure. Le gouvernement de l'Ontario a été confronté à ces deux aspects contradictoires de la question et il en est résulté des changements majeurs dans la politique des droits d'inscription depuis dix ans. Le présent article revient sur l'histoire de la politique des droits d'inscription en Ontario, décrit les récentes évolutions et les principaux défis politiques afférents à l'attitude des différentes institutions envers la réglementation actuelle qui expirera au terme de l'année universitaire 2009-2010. 


\section{INTRODUCTION}

Policy-makers and institutional administrators have long struggled with the question of college and university student tuition fees. In many ways this struggle may be characterized as a negotiation between two distinct policy goals: providing revenue to adequately finance higher education and ensuring student accessibility to higher education. On the one hand, maximizing flexibility around student fees helps diversify and increase resources to support higher education institutions. On the other hand, capping fees and maintaining a reasonable level of fee homogeneity (among programs and institutional types) help support access.

Recent history in the Canadian province of Ontario illustrates the challenges involved in balancing institutional resource needs with access concerns. The last 10 years have seen considerable change in the Government of Ontario's policy toward tuition fees at publicly assisted universities and colleges of applied arts and technology (CAATs). Prior to 1998, universities and colleges would wait for an annual government announcement on how much tuition they could charge for the coming academic year. This amount would be described as a percentage increase over the previous year, but it was also tied to a "formula fee" contained in the respective provincial operating grants' manual for the university and college sectors. The formula fees acted as an anchor for fees across programs and institutions, allowing some differentiation but largely keeping all fees within a relatively narrow band. There was little, if any, differentiation among individual universities and among individual CAATs.

This pattern of incremental tuition fee increases changed dramatically in the 1998-99 academic year. Tuition fees for some programs were decoupled from the formula fee, tuition differentiation among programs was written into policy, and tuition differentiation among institutions occurred. A change in the provincial government led to a tuition freeze in 2003-04, followed by a new tuition framework introduced in 2006-07.

This article provides a historical overview of the policy changes that took place in 1998-99, the amendments made by the 2006-07 framework, and outstanding policy issues arising from the combined effects of these changes. Policy analysis is employed to examine how the current tuition policy appears to be having unintended consequences in terms of institutional behaviour, including a possible attempt to circumnavigate restrictions on tuition fee increases. The aims of successive tuition policies in Ontario are discussed but not the impact of these policies on student demand for and access to university education. Although significant, this topic has been addressed elsewhere, notably by Junor and Usher (2005, 2006), Kelly and Shale (2004), Quirke and Davies (2002), and Usher and Steele (2006). Furthermore, it may still be too soon to assess the full impacts of the 2006-07 to 2009-10 tuition policy on student demand and access. 


\section{BACKGROUND (1980-1998)}

Universities in Ontario have the legal freedom to set student tuition fees at whatever level they wish. However, since the 1960s, the provincial government has essentially capped tuition fees by tying university operating grants to revenue collected through tuition. Tuition policy caps the per-student fee an institution may charge for a given program of study. The traditional penalty for overcharging a student is a reduction in the offending institution's operating grant equal to the total amount of revenue gained by the tuition overcharge (Smith et al., 1996). Prior to 1980, university tuition-fee caps were defined by the formula fee used by the then-Ministry of Colleges and Universities to calculate university operating grants (for more details on the formula fee process, see Appendix 1).

For the 1980-81 academic year, the Ministry permitted universities to charge tuition fees that were $110 \%$ of the formula fee, as defined by the Ontario Operating Funds Distribution Manual (MTCU, 2004), without financial penalty. This limited tuition flexibility was referred to as "discretionary fees"; the purpose of this policy was to allow universities to access increased operating revenue through tuition fees while not increasing the public grant value of the per-student funding calculation. Table 1 describes how successive amendments to the Ontario tuition fee policy between 1980 and 2004 increased the percentage of the formula fee that universities were permitted to charge in tuition.

A consequence of tying tuition increases to the formula fee was that tuition levels of programs were relatively consistent among universities and among programs. Although universities' governing boards had the legal authority to set tuition fees at any level they wished, universities typically avoided doing so under the threat of losing operating grant revenue. University boards also had the option of either not increasing tuition or increasing their fees at a slower rate than their sister institutions. More often than not, however, universities took the maximum permitted tuition increase in any given year, which led to minimal tuition differentiation among Ontario universities. One of the few requirements placed on universities' spending of tuition fee revenue was the Ministry's "tuition set-aside" policy. This policy, introduced in 1996-97, directed all institutions to profile a percentage of their tuition fee increases to institutional student financial assistance (for more details on Ontario's tuition set-aside policy, see Appendix 2).

\section{ADDITIONAL COST RECOVERY (1998-2004)}

On May 6, 1998, a memo from the Ministry of Training, Colleges and Universities (MTCU) to the province's universities and CAATs established a new paradigm for tuition policy in Ontario. The memo introduced complete deregulation of tuition fees for graduate, some undergraduate, and some professional university programs, as well as for "high demand" and post-diploma programs 
Table 1. Annual Maximum "Discretionary Fee" Levels for Ontario Universities

\begin{tabular}{|c|c|c|}
\hline Year(s) & Discretionary Fee Maximum ${ }^{1}$ & Other Requirements \& Issues \\
\hline $1980-87$ & $110.0 \%$ & None \\
\hline 1987-1996 & $113.0 \%$ & None \\
\hline 1997-1997 & $133.0 \%$ & $\begin{array}{l}\text { Institutional revenue may not exceed } 123 \% \\
\text { of calculated total formula fee revenue across } \\
\text { programs and } 10 \% \text { of annual new fee revenue } \\
\text { must be set aside for institutional student } \\
\text { financial assistant (please see Figure } 2 \text { : Tuition } \\
\text { Set-Aside for a further discussion of this } \\
\text { policy). }\end{array}$ \\
\hline 1997-1998 & $159.6 \%$ & $\begin{array}{l}30 \% \text { of annual new fee revenue must be set } \\
\text { aside for institutional } \\
\text { student financial assistance. }\end{array}$ \\
\hline 1998-1999 & $175.56 \%$ & $\begin{array}{l}\text { Only applied to "tuition-regulated" programs } \\
\text { and 30\% of annual new fee revenue must be } \\
\text { set aside for institutional student financial } \\
\text { assistance. }\end{array}$ \\
\hline 1999-2000 & $191.52 \%$ & $\begin{array}{l}30 \% \text { of annual new fee revenue must be set } \\
\text { aside for institutional } \\
\text { student financial assistance. }\end{array}$ \\
\hline $2000-2001$ & $229.82 \%$ & $\begin{array}{l}30 \% \text { of annual new fee revenue must be set } \\
\text { aside for institutional } \\
\text { student financial assistance. }\end{array}$ \\
\hline 2001-2002 & $275.79 \%$ & $\begin{array}{l}30 \% \text { of annual new fee revenue must be set } \\
\text { aside for institutional } \\
\text { student financial assistance. }\end{array}$ \\
\hline 2002-2003 & $281.09 \%$ & $\begin{array}{l}30 \% \text { of annual new fee revenue must be set } \\
\text { aside for institutional } \\
\text { student financial assistance. }\end{array}$ \\
\hline 2003-2004 & $286.4 \%$ & $\begin{array}{l}30 \% \text { of annual new fee revenue must be set } \\
\text { aside for institutional } \\
\text { student financial assistance. }\end{array}$ \\
\hline
\end{tabular}

Notes:

1 Refers to the maximum allowable discretionary tuition fee in relation to the formula fee of a given program (excepting "Additional Cost Recovery programs" - see below - from 1998-2004). This does not represent actual or average fee increases.

Source: MTCU 2004

in the CAATs. The programs covered by this policy were referred to as "additional cost recovery" (ACR) programs. Although institutions were given total freedom in setting ACR tuition-fee levels, student enrolment in ACR programs still attracted MTCU operating grants, as they had prior to $1998-99 .{ }^{1}$

The government limited ACR status to a specific list of programs, all of which were considered expensive to operate and/or provided a high-earning potential for graduates. The ACR policy included,

- all graduate programs, including Master of Business Administration (MBA) and other professional graduate programs 
- some "second-entry" programs (some previous undergraduate experience was required for admission), including undergraduate business/ commerce, dentistry, law, medicine, optometry, pharmacy, and veterinary medicine;

- some "first-entry" programs (no previous undergraduate experience was required for admission), including undergraduate engineering and computer science programs, that were related to a contemporary government policy called the Access To Opportunities Program (ATOP), which aimed to double enrolment in these programs by 2004-05.

All other university programs continued to have regulated tuition. Universities were permitted to increase their tuition fees "by up to 5 per cent in 1998-99 and up to a further 5 per cent of the 1997-98 fee rate in 1999-2000" and "by an additional increase of up to 5 per cent of the 1997-98 fee rate in each of these two years" (MTCU, 1998, p. 1). However, institutions had to produce an annual Quality Improvement Plan explaining how these fee increases had benefited students. Universities were also limited to an annual maximum tuition increase of 20\% for any single program (MTCU, 1998).

In exchange for the increased tuition-setting freedom of ACR, institutions were required to commit to special student financial assistance provisions for ACR program students. In most cases, the publicly administered student aid program, the Ontario Student Assistance Plan (OSAP), only recognized tuition fees up to $\$ 4,500$ per year, ${ }^{2}$ so institutions were required to provide financial assistance for those students the OSAP system assessed to be "in need" for their fees above the $\$ 4,500$ threshold (MTCU, 1998, 2004). In this way, institutions were compelled to assume some responsibility for the increased tuition burden on students.

Universities had been advocating for increased flexibility in the tuition setting for some time, as evidenced by multiple government reports and reports to government prior to and after 1998 (Association of Colleges of Applied Arts and Technology of Ontario, 2004; Leggett, 2000; Rae, 2005; Smith, 2000a; Smith, 2000b; Smith et al., 1996; Stager, 1989). Consequently, institutions took advantage of the opportunity to increase their fees. Medicine, law, and MBA programs experienced the greatest fee increases of the ACR programs, while engineering and computer science programs saw modest fee increases, although not to the same magnitude as the other professional programs. Academic graduate programs, such as masters' and PhD programs, did not have the levels of fee increase experienced in the professional programs because universities would have had to increase student assistance in these programs to entice students to enrol in them, potentially negating any benefit of significant tuition increases.

The ACR tuition policy opened the door to considerable tuition differentiation in ACR programs across universities, severing the tie between tuition-fee setting and the formula fee. The only limiting factors on ACR tuition levels were market forces and the institutional student aid provisions articulated in the May 6, 1998, memo. 


\section{A TUITION FREEZE AND A NEW TUITION FRAMEWORK (2004-2010)}

The 2003 provincial general election led to a change in government in Ontario. One of the new government's platform commitments had been a tuition freeze during which a review of Ontario's higher education would take place. Tuition fees for both regulated and ACR programs were frozen at 2003-04 levels. Institutions were instructed that they could not increase fees in any MTCUfunded program for the academic years 2004-05 and 2005-06 without being subject to a commensurate reduction in their operating grants. Consequently, differential tuition levels that had grown out of the ACR policy were frozen in place. To compensate institutions, the Ministry provided grants to offset foregone tuition increases based on historic increases in both regulated and ACR programs. This compensation amounted to \$48 million in 2004-05 and \$115 million in 2005-06 (MTCU, 2006a).

In 2006, following the conclusion of a provincial review of higher education, the Minister of Training, Colleges and Universities announced a new tuition framework for CAATs and universities (MTCU, 2006a). This policy came into effect in 2006-07 and was intended to be in place until 2009-10. The new tuition-fee framework permitted limited tuition flexibility but re-regulated all programs, including former ACR programs. ${ }^{3}$ Tuition fees of former ACR programs were not rolled back to pre-1998 levels, however; future increases to these programs' fees were to be based on whatever fee level had been charged at each university in the 2003-04 academic year.

The new tuition framework continued the policy of differentiating between groups of programs, just as the 1998-2004 policy had done. The new framework divided programs into undergraduate/first-entry and professional/ graduate/high demand for universities and into diploma/first-entry and postdiploma/high demand for CAATs (MTCU, 2006b). Programs falling within the professional/graduate/high-demand and the post-diploma/high-demand categories were analogous to the ACR program lists used for the previous tuition policy. The new policy allowed universities and CAATs to increase first-year students' tuition by a maximum of $4.5 \%$ for undergraduate/first-entry and diploma/first-entry programs and by a maximum of $8 \%$ for professional/graduate/high-demand and post-diploma/high-demand programs over the previous year's tuition fees. All program tuition-fee increases for upper-year students were limited to $2 \%$ per year, and no institution was permitted to increase its overall tuition fees by more than a weighted average of 5\% in any given year without facing financial penalties. These penalties included reimbursing students the fee overcharge or a reduction in government operating grants equal to the value of the fee overcharge.

The policy goal of separating academic programs and applying different fee structures to them was to limit fee increases in those programs that were typically considered a first step into higher education for potential students. The programs falling into the categories of undergraduate/first-entry included most programs that students enter immediately after graduation from secondary school. 
The framework also created "tuition cohorts" of students. Depending on the program, students in the first year of a program could be charged up to 4.5\%or 8\% more than first-year students the previous year. Students going into the second year of their program could not face more than a $2 \%$ increase in their fees over their first year. Theoretically, full-time students entering a program together and successfully progressing through their program would never see more than a $2 \%$ increase in their tuition fees for each subsequent year of their program. Students one year below would be paying a higher rate of tuition and students one year ahead would be assessed a lower rate of tuition. In order to maintain the tuition-cohort principle, the framework clearly stated that institutions could not "bank" tuition increases over multiple years (e.g., take no tuition increases over two or more years and then increase first-year tuition by 15\%). The permitted percentage increases were annual limits.

\section{THE NEW TUITION FRAMEWORK: DISCUSSION}

The 2006-10 tuition framework was not a new direction for tuition policy in Ontario, although it did introduce a few significant policy changes. It may be more accurately described as an amendment to the previous 1998-2004 tuition policy. The new framework did not repeal or roll back the dramatic tuition-fee increases seen in many university professional programs, college high-demand programs, and university and college second-entry programs. Rather, it simply assumed all Ontario CAAT and university tuition fees as of 2003-04 as a base tuition level and regulated future increases accordingly.

The new tuition framework clearly attempted to address outstanding issues arising from the goal of student access, while maintaining some of the principles established by the 1998-2004 ACR policy toward resourcing CAATs and universities. However, the intersection of these competing policy goals created a number of new dilemmas.

\section{Predictability}

One of the policy goals of the new framework was to increase the predictability of tuition fees for full-time students. This goal was consistent with recommendations made by the final report of the government-commissioned 2004-05 Ontario Postsecondary Education Review, Ontario: A Leader in Learning (Rae, 2005), and with student recommendations (Bender \& Mayer, 2005; Stewart, 2004). By creating tuition cohorts of student enrolment, full-time students could theoretically calculate the maximum amount of their academic programs' total tuition fees based on the tuition fee charged in their first year of study. Thus, students who began an undergraduate honours program in September 2007 would know that their tuition fees would not go up by more than $2 \%$ for each year they remained in the program in full-time study.

For universities and colleges with predominantly full-time student enrolment, where students progress through program years in a relatively predict- 
able fashion, the tuition framework's predictability policy was relatively easy to implement and apply. Full-time students would typically flow through their program as a cohort, completing their program with the same students with whom they began their program. However, for institutions with large part-time student populations, variable work terms (such as those found in co-operative education programs), and/or modular programming, the cohort model presented significant administrative challenges. Students at this type of institution do not follow a traditional progression though their studies: students may be taking both first- and second-year classes in the same term; their first-year courses may be spread over two academic years; or they may have one final academic term in what is technically their fifth year of study in a four-year program. Based on the existing tuition framework, it is unclear, then, how these students should be treated for the purposes of tuition assessment. Institutions encountering these policy challenges may forego potential additional tuition revenue in favour of ensuring compliance with the tuition framework.

\section{Overall Weighted-Average Tuition Increases}

Another particularly interesting aspect of the new policy framework is that no single institution's overall weighted-average tuition increases can represent more than a 5\% increase over the previous year's tuition levels. This aspect was intended to prevent institutions from dramatically increasing enrolment in programs with relatively low costs but high tuition fees. For example, law and MBA programs are expected to have a lower delivery cost compared to programs such as medicine and engineering. However, these lower deliverycost programs are permitted higher fee increases than undergraduate arts programs. By limiting annual weighted institutional tuition increases, the tuition framework protected enrolment for those programs that mandate lower yearover-year fee increases-because those lower-fee programs became necessary to moderate the institutional effect of greater increases in other programs. From a public policy perspective, protecting enrolment in traditional entry-level programs supported the provincial goal of increasing post-secondary education participation rates.

\section{Increased Institutional Tuition Differentiation}

A third interesting aspect of this tuition fee policy is its decoupling of university tuition increases from the programmatic formula fee. As a consequence, all tuition fee increases are based on the precedent at each individual institution, rather than a single, centrally controlled base fee. Furthermore, as previously noted, an institution cannot bank increases not taken in any given year. For example, Institution A puts in place a $2 \%$ tuition increase for the second year of an undergraduate arts program in 2008, but Institution B does not. In 2009, Institution A may increase its tuition fees by another $2 \%$, equating to a total percentage increase of 4.04\% over two years. However, Institution B may 
not increase its tuition fees by $4.04 \%$ in one year; it is limited to a $2 \%$ increase of upper-year tuition fees. Thus, the new tuition policy, by decoupling tuition increases from the formula fee, has theoretically increased the chances of institutional tuition differentiation across all programs.

However, institutions with more resources will obviously be in a position to spend more on their programs and services than institutions with lower tuition rates. Although no institution is compelled to increase its tuition fees in any given year, the opportunity to maximize tuition income rests with those institutions who have taken the annual maximum increase. Indeed, the new tuition policy actually encourages institutions to always take the maximum tuition increase available to them for fear of being left behind their competitors.

\section{Program Approvals}

According to the 2006-10 tuition framework, new programs submitted to MTCU for approval must include a proposed tuition fee for the first year of the proposed program (MTCU, 2006b). This was not a requirement of the MTCU program-approval process prior to 2006. Since the tuition framework clearly regulates the maximum allowable tuition increases after the first year of a new program's operation, institutions must carefully consider what fee to propose for any new program to guarantee the program's future financial solvency.

The university tuition framework states that proposed tuition fees for programs submitted for Ministry approval may be "up to a level commensurate with the tuition charged for comparable university programs in Ontario" (MTCU, 2006 b, p. 4). Comparability of programs is based on a number of factors, including: 1) the credential earned by students who complete the program; 2) course and program design; and 3) the institutionally proposed BIU (basic income unit) weight of the program submitted for approval. This aspect of the tuition framework was designed to ensure a level of fairness in setting the tuition levels of new programs by preventing advantaged institutions from introducing new programs and then arguing for a higher first-year tuition fee than institutions with the same or similar programs.

\section{Unaddressed Policy Issues}

Two policy issues are not addressed by the tuition framework's approach to new programs. The first is the question of what to do in the event that a proposed program has no comparable program at an Ontario university or CAAT. Although a new program is unlikely to be so unique that it could not be compared to any existing program in Ontario, in such a case, it would appear logical to consider programs at other Canadian institutions, recognizing that other provinces have different funding regimens for their universities and colleges and that these differences will impact tuition-fee levels for programs outside of Ontario. Indeed, institutions are likely to attempt to make the argument that a proposed program is unique in an effort to maximize the approved 
level of tuition for the new program, even if there are comparable programs as defined by the policy.

The second issue arises from a complication with the previous tuition policy. Under the 1998-2004 policy, significant differentiation in tuition-fee levels emerged among universities, particularly in undergraduate law (LLB) and undergraduate medicine (MD). The introduction of the tuition freeze in 2004 pinned tuition-fee levels, including those of former ACR programs, at whatever level they had achieved as of 2003-04 and locked in the fee discrepancies that existed between institutions.

\section{The Case of Law Tuition}

Of particular note among these tuition-level discrepancies is undergraduate law. There are six programs in the province preparing students for entry to practice law in Ontario. As of $2007-08$, over $\$ 8,700$ per year in fee charges separated the University of Windsor's law tuition, at the low end, from that of the University of Toronto, at the high end. A wide range of tuition fees currently exists among Ontario's law schools, as illustrated in Table 2.

Table 2. First-year Law Tuition, by Year and by Institution

\begin{tabular}{lcccccc}
\hline Academic Year & Toronto & York (Osgoode) & UWO & Queen's $^{\text {Ottawa }}$ & Windsor \\
\hline $2007-08$ & $\$ 18,662$ & $\$ 13,996$ & $\$ 10,530$ & $\$ 10,452$ & $\$ 9,914$ & $\$ 9,910$ \\
\hline
\end{tabular}

${ }^{1}$ Refers to Common Law program. Ottawa also has a French language civil law program which has a different fee level.

Source: Common University Data Ontario, COU

Universities have expressed dissatisfaction with this situation. Some universities argued that because the University of Toronto law school took advantage of larger fee increases while the government's ACR policy was in place, it will now enjoy much higher fees than any other law school for the foreseeable future. Queen's University, with the support of other law schools, has argued that all universities should be permitted to raise their LLB program fees to a point consistent with Toronto's fee level (Alphonso, 2005).

Furthermore, in 2001, the University of Toronto reclassified its law program as leading to a juris doctor, or JD, designation versus the conventional Canadian bachelor of laws, or LLB, designation. This change did not require a significant alteration to Toronto's existing law program and was done to allow its law graduates to be more marketable to American law firms, where the JD is the equivalent of a Canadian LLB. The other five Ontario faculties of law did not follow suit. However, recent reports that Queen's University was considering changing its law school's credential from an LLB to a JD were confirmed in a November 2007 article in the Globe and Mail newspaper (McNish, 2007). Then, on November 28, 2007, The Queen's Journal, the university's student paper, reported that the proposed credential change had passed the Queen's Law Faculty 
Board and would be going to the University Senate for final approval (Kim \& Jemison, 2007). The argument presented for this proposed change in credential focuses on the marketability of Ontario law graduates in the United States, as it had at the University of Toronto.

There may also be another motivation for the Queen's University law program to move to a JD designation. One possible means of circumnavigating the tuition framework would be to propose a material change to a law program that would permit a higher fee level. Queen's may present the provincial government with the argument that by changing their law program's credential to a $\mathrm{JD}$, they are making a material change to their program and, because the closest comparable law program with the same credential is the University of Toronto, Queen's law tuition should be set at a level consistent with the University of Toronto. If this is Queen's strategy, it would appear that the existing tuition framework would support its argument and the Ministry of Training, Colleges and Universities would have to permit Queen's to re-profile its law tuition fees with the other JD program in Ontario-at the University of Toronto. Presumably, the only way for MTCU to avoid having to make this judgment would be for the government to reject any proposed JD program submission Queen's may make to the Ministry, but given that the Ministry permitted the University of Toronto to change its law credential to a JD, it would be difficult for it to justify rejecting a similar request from Queen's. The re-profiling of existing programs represents a loophole in the government's new tuition policy.

\section{CONCLUSIONS}

It is unclear whether or not the policy implications discussed above were intended by the Ministry. Government-commissioned reports have argued in favour of increased tuition-setting flexibility for universities in order to increase diversification and differentiation between institutions (Rae, 2005; Smith et al., 1996). These reports assumed that market forces will guide tuition fees and that a range of fees in all programs across institutions should emerge. The complete decoupling of tuition from the formula fee appears to support this policy goal.

Institutions, however, appear to be pursuing avenues to circumnavigate the regulatory features of the tuition policy in an effort to match the tuitionfee levels and resources of other institutions, an activity that counteracts the fee differentiation achieved by decoupling tuition increases from the formula fee. In effect, this institutional behaviour would castrate the fee increase limits defined by the policy and leave regulation of tuition in the hands of whichever institution is able to charge the highest fees.

As other Canadian provinces and, indeed, other countries struggle with policy issues surrounding tuition fees, Ontario's experience becomes a lesson in policy development. English and Welsh universities, having introduced socalled "top up" fees in 1997 and "variable fees" in 2006, now advocate for some form of limited fee flexibility, using the same arguments for and some of the same policy goals of Ontario's fee policy (Coughlan, 2009). As international 
attention turns to Ontario and how it responds to the emerging challenges of its fee policies, policy-makers must continue to refine and improve the existing policy to ensure its fairness and sustainability in the face of institutional attempts to maximize resources.

\section{APPENDIX 1}

\section{Formula Fee}

The formula fee is a figure used by the Ontario Ministry of Training, Colleges and Universities (MTCU) to calculate university operating grant entitlements. The notional operating grant value of any one university student is dependent on two factors: 1) the basic operating income (BOI) associated with the student's program, which is intended to reflect the total cost to educate one student in that program, and 2) the formula fee, representing the student's tuition fees associated with that program. Although the original formula fees were intended to reflect actual tuition fees, the current fees were established in 1979 and have not been amended (MTCU, 2004).

The formula fee is deducted from the BOI to give the basic income unit (BIU) of that student for operating-grant calculation purposes. This calculation takes the total cost of educating a student in a given program and subtracts that formula fee, leaving the total grant the Ministry makes to an institution to support that student's studies. The formula for determining the notional grant value of a full-time university student may be expressed as:

$$
\mathrm{BIU}=\mathrm{BOI}-\text { (formula fee) }
$$

The value of the BOI and, hence, the BIU may fluctuate from year to year because the value of the BOI is dependent on the total value of the operatinggrant envelope allocated to the Ministry through the provincial budget. Different academic programs are assigned different "weights," which are theoretically relative to the cost of operating the program on a per-student basis. For example, a first-year undergraduate arts student has a weight of 1 , while a finalyear medical student has a weight of 5. Therefore, the notional cost to educate a medical student is assumed to be five times more than that of a first-year arts student. These weights were set by the government and have not been altered for some time, although new programs are added periodically. The formula fees contained in Ontario's current Operating Funds Distribution Manual do not reflect actual tuition-fee levels (MTCU, 2004).

\section{APPENDIX 2}

\section{Tuition Set-Aside}

Starting in the 1996-97 academic year, Ontario universities and CAATs were required to devote a minimum of $10 \%$ of their increased tuition revenue to 
institutional student financial assistance (SFA). The total dollar figure for each institution was a function of the new tuition revenue generated by the 1996-97 tuition increase over that generated in 1995-96. The purpose of this "tuition set-aside" policy was to ensure that all universities and CAATs had some form of institutional SFA. In subsequent years the percentage amount of tuition setaside was increased to 30\% for each year an institution increased its tuition fees over the previous year.

The Ministry of Training, Colleges and Universities tracked the total amount of tuition set-aside that institutions should make in any given year to ensure that they were dedicating the correct amount of tuition revenue to SFA. The total amount of tuition set-aside that an institution needed to allocate in any given year was cumulative, including all previous years' allocations back to 1996-97.

Tuition set-aside funds were, and continue to be, intended for needs-based SFA, although merit-based scholarships given to students in financial need are permissible (MTCU, 2004). As of 2006-07, institutions were no longer required to set aside a percentage of new tuition revenue arising from tuition increases. However, they are still required to maintain existing tuition set-aside allocations, and these amounts may fluctuate based on overall student enrolment.

\section{NOTES}

1 Prior to 1998, universities were permitted to make a program "full cost recovery," provided the institution was prepared to lose operating grants to support the program in question. Such programs are referred to as being "off grant” and include Queen's University's Executive Master of Business Administration program.

2 OSAP would recognize up to $\$ 5,350$ in fees for students in co-operative education programs (MTCU, 2004).

3 This re-regulation did not include international student tuition fees, which, with a few exceptions, were fully deregulated as of 1996-97 (MTCU, 2004).

\section{REFERENCES}

Alphonso, C. (2005, December 22). Close tuition gap, law schools ask. Globe and Mail, p. A13.

Association of Colleges of Applied Arts and Technology of Ontario. (2004, November). Achieving high expectations in Ontario's postsecondary education sector: A plan for change. Retrieved March 30, 2008, from http://www.collegesontario.org/Client/CollegesOntario/Colleges_Ontario_LP4W_LND_WebStation. nsf/resources/Additional/\$file/CO_RAE_REVIEW_SUBMISSION.pdf

Bender, H., \& Mayer, S. (2005, October). Multi-year plans in Ontario: Securing a bright future (policy document). Toronto: Ontario Undergraduate Student Alliance. 
Coughlan, S. (2009, March 17). Universities push for higher fees. BBC News. Retrieved March 17, 2009, from http://news.bbc.co.uk/go/pr/fr/-/1/hi/education/7946912.stm

Council of Ontario Universities (COU). (2007). Common university data Ontario. Retrieved November 22, 2007, from www.cou.on.ca/_bin/relatedSites/ cudo.cfm

Junor, S., \& Usher, A. (2005). The college-university divide: Access issues in post-secondary education. Education Canada, 45(4), 55-58. Retrieved November 15, 2008, from http://www.cea-ace.ca/pub.cfm?subsection=edu\&page $=$ arc \&subpage $=$ fal0 5

Junor, S., \& Usher, A. (2006). Student aid time-bomb: The coming crisis in Canada's financial aid system. Canadian Educational Report Series. Retrieved November 16, 2008, from ERIC database.

Kelly, W., \& Shale, D. (2004). Does the rising cost of tuition affect the socioeconomic status of students entering university? Retrieved November 16, 2008, from ERIC database.

Kim, R., \& Jemison, L. (2007). A law degree by any other name. The Queen's Journal, 135(23). Retrieved November 30, 2007, from http://www.queensjournal.ca/story/2007-11-28/news/law-degree-any-other-name/

Leggett, W. (2000). Queen's at the crossroads. The Queen's University Alumni Review, Fall, p.12.

McNish, Jacquie. (2007, November 14). LLB or JD? Fierce debate a matter of degree. Globe and Mail, p. B10.

Ministry of Training, Colleges and Universities (MTCU). (1998, May 6). Conditions and implementation provisions associated with tuition increases in 1998-99 and 1999-2000 (policy document). Toronto: Author.

Ministry of Training, Colleges and Universities (MTCU). (2004, December). The Ontario operating funds distribution manual: A manual governing the distribution of Ontario government operating grants to Ontario universities and university-related institutions, 2003-04 fiscal year. Toronto: Author.

Ministry of Training, Colleges and Universities (MTCU). (2006a, March 8). McGuinty government plan to improve quality and access in postsecondary education (media release). Retrieved March 30, 2008, from http://ogov.newswire. ca/ontario/GPOE/2006/03/08/c0202.html?lmatch=\&lang=_e.html

Ministry of Training, Colleges and Universities (MTCU). (2006b, April 20). Guidelines for implementation of the tuition fee policy for publicly-assisted universities, 2006-07 to 2009-10 (policy document). Toronto: Author.

Quirke, L., \& Davies, S. (2002). The new entrepreneurship in higher education: The impact of tuition increases at an Ontario university. Canadian Journal of Higher Education, 32(3), 85-109. 
Rae, B. (2005). Ontario - A leader in learning: Report and recommendations of the advisor to the Premier and the Minister of Training, Colleges and Universities. Toronto: Queen's Printer for Ontario.

Smith, D. C. (2000a). "How will I know if there is quality?" Report on quality indicators and quality enhancement in universities: Issues and experiences. Toronto: Council of Ontario Universities.

Smith, D. C. (2000b). "Will there be enough excellent profs?" Report on prospective demand and supply conditions for university faculty in Ontario. Toronto: Council of Ontario Universities.

Smith, D. C., D.M. Cameron, F. Gorbet, C. Henderson and B. M. Stephenson. (1996). Excellence, accessibility, responsibility: Report of the Advisory Panel on Future Directions for Postsecondary Education. Toronto: Queen's Printer for Ontario.

Stager, D. (1989). Focus on fees: Alternative policies for university tuition fees. Toronto: Council of Ontario Universities.

Stewart, G. (2004, October). Three pillars: Funding, tuition and student financial assistance (discussion document). Toronto: Ontario Undergraduate Student Alliance.

Usher, A., \& Steele, K. (2006). Beyond the 49th parallel II: The affordability of university education. Retrieved November 16, 2008, from ERIC database.

\section{ACKNOWLEDGEMENTS}

This article would not have been possible without the support of the Higher Education Quality Council of Ontario (HEQCO). In particular, the author thanks HEQCO Vice-President, Research, Dr. Ken Norrie for his guidance and advice.

\section{CONTACT INFORMATION}

Andrew Michael Boggs

Department of Education

Linacre College, University of Oxford

Oxford, United Kingdom

0X13JA

andrew.boggs@education.ox.ac.uk

Andrew Michael Boggs was a research director with the Higher Education Quality Council of Ontario (HEQCO) and holds an MA from the University of Toronto, Ontario Institute for Studies in Education, in higher education policy and history. He served as a policy adviser with the Ontario Ministry of Training, Colleges and Universities from 1999-2006. He is currently pursuing a doctorate in higher education policy at the University of Oxford. 